\title{
Sea-level rise, expected environmental changes, and responses of intertidal benthic macrofauna in the Humber estuary, UK
}

\author{
Toyonobu Fujii ${ }^{1,2, *}$, Dave Raffaelli ${ }^{1}$ \\ ${ }^{1}$ Environment Department, University of York, Heslington, York YO10 5DD, UK \\ ${ }^{2}$ Present address: Oceanlab, University of Aberdeen, Main Street, Newburgh, Aberdeenshire AB41 6AA, UK
}

\begin{abstract}
In many European estuaries, extensive intertidal habitats could vanish in the future due to rising sea levels that squeeze tidal flats against established sea defences. The remaining intertidal area is likely to become steeper with coarser sediment, and saline water may intrude upstream due to increased water depth and enhanced wave energy. This paper investigates the impacts of sea-level rise on benthic macrofauna in an intertidal habitat in the Humber estuary, UK. Field surveys were conducted between 2003 and 2004 to examine spatial patterns of benthic macrofaunal biomass along the estuarine longitudinal gradient and the local beach width gradient. Multiple regression analysis revealed that $>80 \%$ of the observed variation in biomass of the 2 dominant bivalve species Macoma balthica and Cerastoderma edule, and the total biomass of other macrobenthic species, could be explained by key environmental variables such as salinity, sediment characteristics and morphological factors. Physical data for the Humber estuary were assessed to predict the likely course of changes in these key environmental variables in response to sea-level rise. Model simulations showed that a sea-level rise of $0.3 \mathrm{~m}$ would result in a $6.7 \%$ loss of intertidal area and $6.9 \%$ loss of total macrobenthic biomass, and that saline intrusion could partly compensate for such loss of macrobenthic biomass. However, associated environmental changes, such as beach slope steepening and sedimentary shifts, could have overriding negative impacts with potential loss of macrobenthic biomass of up to $22.8 \%$, depending on the extent of environmental changes.
\end{abstract}

KEY WORDS: Estuarine ecosystems - Benthic macrofauna · Sea-level rise · Coastal squeeze • Environmental changes $\cdot$ Biomass $\cdot$ Humber estuary

\section{INTRODUCTION}

Estuarine intertidal flats are physically dynamic environments that harbour high densities and biomass of benthic invertebrates, which in turn provide essential food for epibenthic crustaceans, fish and shorebirds (Goss-Custard et al. 1990, Lawrence \& Soame 2004, McLusky \& Elliott 2004). Benthic macrofaunal species composition, abundance and biomass vary within estuaries, and this variability has been related to key environmental variables such as salinity, sediment type and tidal depth (McIntyre 1970, Boesch
1977, Dankers et al. 1981, Key 1983, Elliott \& Kingston 1987, Jones 1988, Meire et al. 1991, Dauer 1993, Elliott et al. 1998, Beukema 2002, Ysebaert \& Herman 2002, Ysebaert et al. 2003), all of which are likely to respond to accelerated sea-level rise. Although there remains considerable uncertainty in predicting the impact of sea-level rise on estuaries, the following physical processes are expected to be important.

Firstly, the salinity gradient of many estuaries will be affected due to increased estuarine water volume, resulting in widening and deepening, with a concurrent increase in tidal prism and tidal range (Kennish 2002). 
This in turn will lead to greater salt intrusion (Jones 1994), relocating the region of the turbidity maximum (where vigorous mixing of fresh and marine water and intensive particle deposition occur) further upstream. Such an effect would increase local silt accretion rates towards the upper regions of the estuaries, while reducing siltation processes in the lower regions.

Secondly, rising sea levels will reduce the spatial extent of intertidal flats. Estuarine mudflats might be expected to migrate landwards as coastal wave and tidal energy increase, reestablishing their original structure (Pethick 1996, Crooks 2004). However, for many estuaries this will not be possible due to 'coastal squeeze', the process by which saltmarshes and mudflats are eroded away as they become trapped between rising sea levels and fixed sea defences (Jones 1994, Galbraith et al. 2002). This could lead to substantial losses of intertidal area.

Thirdly, increased water depths and a more energetic wave climate will change coastal geomorphology and sediment particle composition. In the case of open sandy beaches, this will be manifested through changes in the beach's morphodynamic state, moving from a dissipative beach characterised by a flatter slope, low energy conditions and finer sediment, to a reflective state with a steeper slope, higher energy conditions and coarser sediment (Brown \& McLachlan 1990). Similarly, where open coastal flats are situated around the lower region as in a large estuary, there is likely to be a steepening of the shore (Crooks 2004, Taylor et al. 2004) and accumulation of coarser particles due to enhanced wave energy, with consequent changes in the sediment regime (Goss-Custard et al. 1990, Raffaelli \& Hawkins 1996). Combined with shifts in the region of the turbidity maximum, the entire sedimentary distribution within an estuary could shift upstream along the estuarine longitudinal gradient.

Here, we explore how these aspects of the physical environment of the Humber estuary are likely to change in response to sea-level rise, and how such changes might affect intertidal macrobenthic biomass. While other physical change scenarios are possible depending on estuary shape (e.g. Goss-Custard et al. 1990, Beukema 2002), the geography of the Humber estuary lends itself to the scenario described above. Field surveys were conducted in September 2003 and 2004 to obtain data on physical and biological factors of intertidal habitats along (1) the estuarine longitudinal gradient over the entire estuarine system, and (2) the beach width gradient for a restricted area of the estuary where beach width has been progressively altered by historic land claim. Investigation of such environmental gradients and how macrobenthos have adapted to historical land claim provides a basis for predicting how macrobenthos will respond to future coastal squeeze resulting from sea-level rise. Data collected at these sites were used to derive statistical models of how macrobenthic biomass varies along the estuarine longitudinal and beach width gradients. The parameterised models were then used to predict changes in macrobenthic biomass under different sealevel rise scenarios.

\section{MATERIALS AND METHODS}

Study site. The Humber estuary stretches $\sim 60 \mathrm{~km}$ from the confluence of the Trent and the Ouse (Trent falls) to the mouth at Spurn (Fig. 1a). The mean tidal

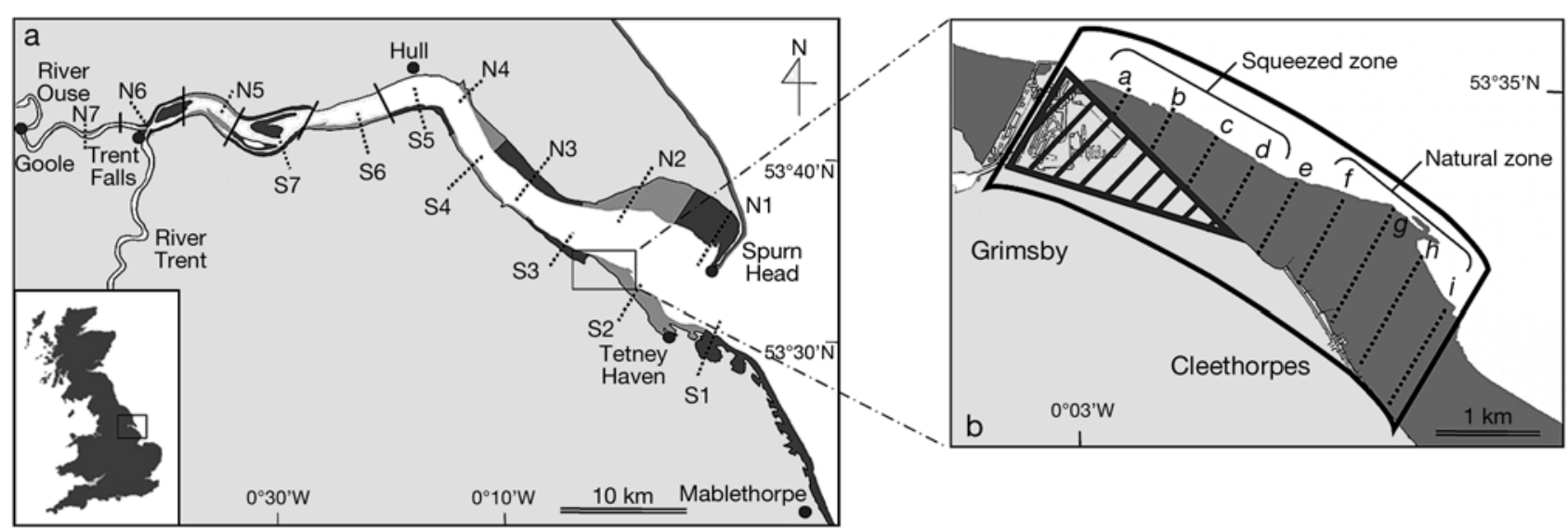

Fig. 1. Humber estuary and Grimsby. (a) Location of Transects N1 to N7 and S1 to S7 (dotted line) along the longitudinal gradient at low tide, showing boundaries between intertidal areas (indicated by dark or mid-gray shading). Where transects represented intertidal areas across the channel, boundaries are indicated by solid lines. The study area covered Goole to Spurn Head on the north bank and to Mablethorpe on the south; the river Trent was not included in this study. (b) Location of study site at Grimsby (within the slightly distorted rectangle), showing 9 transects from a to $i$ (dotted lines) and 2 arbitrary zones with respect to beach width gradient: squeezed and natural (unsqueezed). The triangular hatched area is the reclaimed site that used to be part of the intertidal flat before the mid 19th century 
range is $\sim 5 \mathrm{~m}$ and the maximum spring tide range is $>7 \mathrm{~m}$. The mouth of the Humber estuary is defined in this study as a midpoint between Spurn Head on the north bank and Tetney Haven on the south (Ordance Survey grid ref. 538000, 408000). The system supports a large area of intertidal habitat particularly towards its mouth, and is estimated at $120 \mathrm{~km}^{2}, 90 \%$ of which comprises mudflats and sandflats (Winn et al. 2003). However, in areas with extensive sea defence walls and commercial development such as around Hull and Grimsby, tidal flats are narrow or absent because of truncation by sea defence walls. Sampling sites were selected based on coverage of a range of environmental gradients at uniformly spaced intervals along the longitudinal gradient (Fig. 1). Seven transects each were selected on the north (N1 to N7) and south (S1 to S7) banks of the Humber estuary (Fig. 1a). The Grimsby intertidal flat (Fig. 1b) was also selected because of the marked change in beach width from the southeastern to the northwestern end, a result of extensive land reclamation in front of the town of Grimsby in the mid 19th century (Murby 2001). The beaches at this site are progressively squeezed towards the western end, with a more natural (unsqueezed) gradient to the southeast. Thus, 9 transects were established to cover the whole range of beach width gradients at Grimsby (Fig. 1b). Each transect ran from MHWL (mean high water level) to MLWL (mean low water level) along the direction of tidal ebb. Both MHWL and MLWL were determined with reference to the Ordnance Survey 1:25000 scale map (revised in 2000). Seven sampling stations for transects N1 to S7, and 9 stations for transects $a$ to $i$, were located at evenly spaced intervals over the intertidal profile. Thus, a total of 98 stations $(7 \times 14$ transects $)$ and 81 stations $(9 \times 9$ transects $)$ were sampled along the estuarine longitudinal gradient and the beach width gradient, respectively. Field work was carried out between 8 and 27 September 2003 for transects N2 to S7, and between 14 and 28 September 2004 for transects $a$ to $i$. In addition, only 5 out of 7 stations were sampled along 2 of the transects in the 2003 survey due to difficulties in working in extremely deep mud at the lower part of Kilnsea (Transect N1, Fig. 1a), and to a much shorter length of transect than expected from the map at South Ferriby (Transect S7, Fig. 1a).

Biological measurements and sampling. At each sampling station, 3 cylindrical cores ( $10 \mathrm{~cm}$ diameter) to a depth of $15 \mathrm{~cm}$ were taken on a randomly chosen surface to sample benthic macrofauna. Core samples were sieved on site on a $0.86 \mathrm{~mm}$ mesh with filtered (0.063 mm mesh) sea water. The $0.86 \mathrm{~mm}$ mesh size was employed as it retained a significant fraction of the faunal biomass, but not coarser sediment particles. The organisms collected were preserved in $70 \%$ ethanol for subsequent sorting, species identification, counting and biomass measurements. Identification was made either visually or, where appropriate, under the low power objective of a binocular or compound microscope. Biomass, expressed in $\mathrm{g}$ ash free dry weight ( $\mathrm{g}$ AFDW), was determined by drying $\left(90^{\circ} \mathrm{C}\right.$ for $\left.48 \mathrm{~h}\right)$ and ashing $\left(550^{\circ} \mathrm{C}\right.$ for $\left.3 \mathrm{~h}\right)$ samples after Hartley et al. (1987).

Physical measurements and sampling. Estimates of salinity at each transect were based on monthly measurements made at 40 monitoring stations by the Rivers-Atmosphere-Coast Study (RACS(C)) of NERC's Land-Ocean Interaction Study (LOIS), and taken as the mean salinity for the 12 mo period from March 1994 to March 1995 (Uncles et al. 1998). Wave exposure for each transect was defined as a simple open angle of the shore (midpoint of each transect) to, or subtended by, the open-sea horizon, expressed in radians (after Baker \& Crothers 1987).

Three replicate cores (3 $\mathrm{cm}$ diameter) were taken from the top $5 \mathrm{~cm}$ of the sediment at each sampling station for sediment analysis. Organic matter content was measured as loss on ignition over $16 \mathrm{~h}$ at $375^{\circ} \mathrm{C}$, after Sutherland (1996). Particle size composition and silt content were determined by both wet sieving (for particle sizes $<0.063 \mathrm{~mm}$ ) and dry sieving (for particle sizes $>0.063 \mathrm{~mm}$ ), passing the sample through a tower of sieves with successively smaller mesh sizes. Median particle size was derived graphically (Holme \& McIntyre 1971) and expressed in the Wentworth scale (phi) as follows:

$$
\begin{gathered}
\text { Wentworth scale (phi) }= \\
-\log _{2} \text { of the diameters in } \mathrm{mm}
\end{gathered}
$$

The tidal depth (elevation) of each station in relation to the MHWL was determined using a theodolite and a staff. The MHWL at each transect was taken as the obvious drift line uniformly found on sea defence walls, beaches, or fringing saltmarshes. Beach width was measured in a horizontal straight line between the MHWL and MLWL along the direction of tidal ebb taken from the Ordnance Survey 1:25000 scale map. Because tidal range varies along the longitudinal gradient, the local mean tidal range was calculated as:

$$
\begin{gathered}
\text { Mean tidal range }=(\text { mean spring tidal } \\
\text { amplitude }+ \text { mean neap tidal amplitude }) / 2
\end{gathered}
$$

Beach steepness was estimated at the transect scale (transect slope) and at the station scale (station slope). Transect slope was measured differently depending on where the MHWL (drift line) was located in relation to the highest part of the beach:

$$
\begin{gathered}
\text { Transect slope }= \\
-\log _{10}(\text { mean tidal range } / \text { beach width })
\end{gathered}
$$

where MHWL is located on the beach (sedimentary part), or 
Transect slope $=-\log _{10}$ (height between top of shore \& MLWL / beach width)

where MHWL is found on the sea defence wall, so that steepness of transect only reflects the sedimentary part of the beach. In addition, the slope at each station was calculated as follows:

$$
\begin{gathered}
\text { Station slope } \\
\text { height }\left(\mathrm{S}_{i-1}-\mathrm{S}_{i+1}\right) / \text { relative width }\left(\mathrm{S}_{i+1}-\mathrm{S}_{i-1}\right)
\end{gathered}
$$

where S denotes station and $i$ represents an arbitrary station number. Finally, the median depth of each transect was determined from the intertidal profile by reading the tidal depth at the point where the horizontal distance from the MHWL reaches $50 \%$ of the total width of the beach.

Data analysis. Biological and environmental variables at the transect scale (mean value of all stations along a transect), and general trends in macrobenthic biomass for each transect, were described by univariate analysis along both estuarine longitudinal and beach width gradients.

Because the bivalves Macoma balthica and Cerastoderma edule accounted for a high proportion of the total biomass ( 25 and $52 \%$, respectively), the biomass of (1) M. balthica, (2) C. edule, (3) other macrobenthic species (others), and (4) all macrobenthic species (total), were analysed separately in relation to environmental variables. The amount of variability explained by the environmental variables was substantially higher at the transect than at the station scale (Fujii 2007); thus, all analyses were performed using values at the transect scale (mean value of stations per transect).

Data for biomass and salinity were normalised by $\log (1000 \mathrm{x}+1)$ and $\log$-transformation, respectively, for subsequent analysis. Stepwise multiple regression analysis was conducted to identify the key environmental variables that best explain the spatial variability in each biomass group at the transect scale. All statistical analyses were performed using SPSS for Windows. The observed variations in biomass were then compared with predicted values at the transect scale to assess the extent to which key environmental variables can explain the observed spatial variation along both longitudinal (Humber estuary ) and beach width (Grimsby) gradients. Model validations were then made by assessing how the graphical fit between predicted and observed total biomass could capture the biological trends over the 2 environmental gradients.

The models were then used to simulate how macrobenthic biomass would vary in response to environmental changes resulting from sea-level rise. In these simulations, sea level was assumed to rise by $0.1,0.3$ and $0.5 \mathrm{~m}$. Equations were formulated for longitudinal (e.g. salinity) and sediment (e.g. particle size) variables as a function of distance from the mouth $(x \mathrm{~km})$. For morphological variables (e.g. slopes), equations were expressed as a function of the degree of sea-level rise. Changes in environmental variables in response to sea-level rise could then be estimated by altering the distance from the mouth $(\mathrm{km})$ or the degree of sealevel rise. Substituting these newly derived values of environmental variables in the macrobenthic biomass models allowed estimation of changes in macrobenthic biomasses in response to sea-level rise. The model outputs from the 2003 survey provided the baseline against which the simulation outputs for the different sea-level rise scenarios $(0.1,0.3$ and $0.5 \mathrm{~m})$ were compared.

\section{RESULTS}

\section{Model parameterisation and validation}

Table 1 shows the biological and physical characteristics for the 14 transects along the longitudinal gradient on the Humber estuary and for the 9 transects along the beach width gradient at Grimsby. The mean biomasses (g AFDW $\mathrm{m}^{-2}$ ) of Macoma balthica, Cerastoderma edule, and other macrobenthic species are shown for the 14 transects (N1 to N7 and S1 to S7) along the longitudinal gradient (Fig. 2a), and for the 9 transects ( $a$ to $i$ ) along the beach width gradient (Fig. 2b). The total macrobenthic biomass (bivalves plus others) was broadly similar for both banks along the longitudinal gradient, increasing from the upper to the lower region of the estuary, although the south bank showed a steep decrease in biomass for the transect situated outside the mouth (Fig. 2a). Macrobenthic biomass also showed a marked response along the beach width gradient, with much higher values in the natural unsqueezed zone (transects $f$ to $i$ ) compared to transects located in the squeezed zone ( $a$ to $d$ ) (Fig. 2b).

The 2 data sets along the 2 environmental gradients (longitudinal and beach width) were pooled to provide parameters for statistical models aimed at predicting changes in macrobenthic biomass in response to sealevel rise. Multiple regression analysis was used to assess the role of the key environmental variables in explaining biomass patterns of Macoma balthica, Cerastoderma edule, the remaining species (others), and all macrobenthic fauna at the transect scale. Overall, the models explained between 66 and $85 \%$ of the variance in macrobenthic biomass (Table 2). Because the degree of variability explained by environmental variables was higher in the first 3 models ( $M$. balthica, $C$. edule and other macrobenthic species) than in the 
Table 1. Humber estuary and Grimsby. Biological and environmental variables with maximum, minimum and mean values along the longitudinal $(\mathrm{n}=14)$ and the beach width $(\mathrm{n}=9)$ gradients.

\begin{tabular}{|c|c|c|c|c|c|c|}
\hline \multirow[t]{2}{*}{ Variable } & \multicolumn{3}{|c|}{-14 transects (entire estuary) - } & \multicolumn{3}{|c|}{9 transects (sub-area) } \\
\hline & Maximum & Minimum & Mean & Maximum & Minimum & Mean \\
\hline \multicolumn{7}{|l|}{ Biological } \\
\hline Mean total biomass ( $\mathrm{g}$ AFDW m ${ }^{-2}$ ) & 22.5 & 0.004 & $8.65^{\mathrm{a}}$ & 14.9 & 0.4 & $6.33^{\mathrm{a}}$ \\
\hline \multicolumn{7}{|l|}{ Environmental } \\
\hline TR (mean tidal range, m) & 5.1 & 4.2 & 4.6 & 4.6 & 4.6 & 4.6 \\
\hline AR (area represented by transect, $\mathrm{km}^{2}$ ) & 26.5 & 0.8 & 8.6 & 1.7 & 0.3 & 1.1 \\
\hline SAL (salinity) & 30.0 & 2.6 & 16.1 & 25.8 & 23.9 & 24.8 \\
\hline EXP (exposure, radian) & 2.0 & 0.0 & 0.3 & 1.0 & 0.7 & 0.8 \\
\hline MD (median particle size, phi) & 4.9 & 2.5 & 4.4 & 3.8 & 2.6 & 2.8 \\
\hline ORG (organic matter content, \%) & 4.2 & 0.6 & 3.0 & 2.6 & 0.7 & 1.5 \\
\hline SIL (silt content, \%) & 90.2 & 4.7 & 65.8 & 49.6 & 3.3 & 16.2 \\
\hline WID (beach width, m) & 2525.0 & 68.0 & 811.0 & 1230.0 & 204.0 & 787.0 \\
\hline T-SLO (transect slope) & 2.8 & 1.2 & 2.0 & 2.6 & 1.8 & 2.2 \\
\hline S-SLO (station slope) & 3.6 & 1.4 & 2.2 & 2.6 & 1.8 & 2.3 \\
\hline M-DEP (median tidal depth, \%) & 88.6 & 9.2 & 45.6 & 89.0 & 21.1 & 61.2 \\
\hline
\end{tabular}

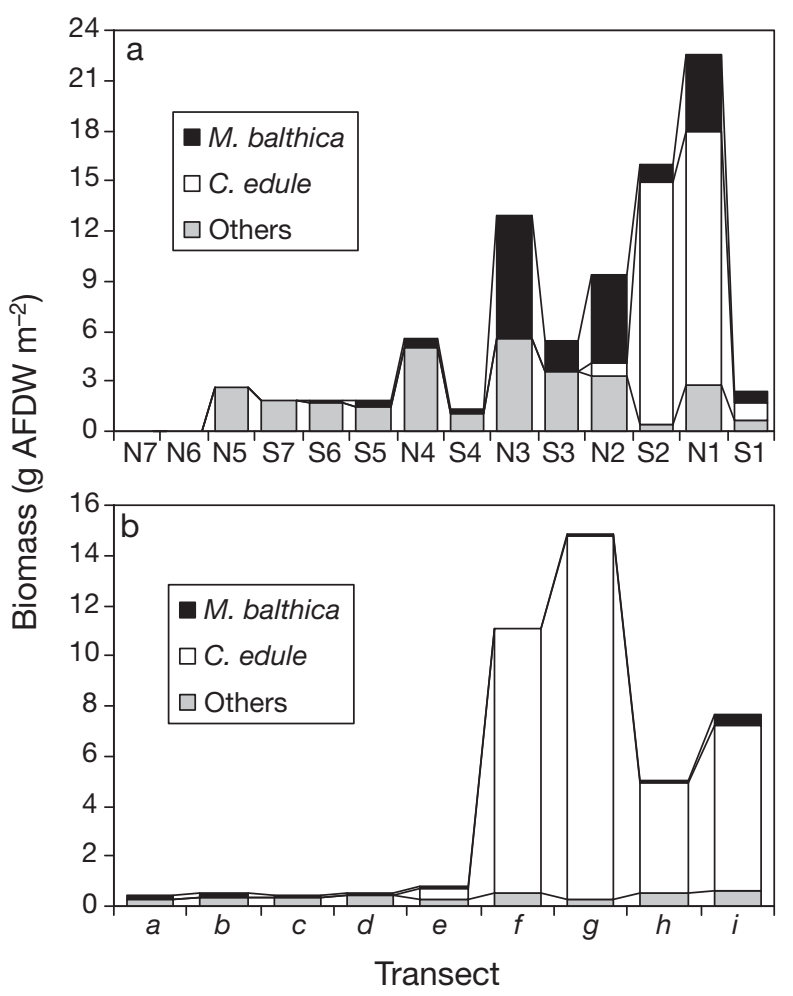

Fig. 2. Macoma balthica, Cerastoderma edule and other macrobenthic species. Mean biomass (g AFDW m ${ }^{-2}$ transect $^{-1}$ ) for (a) 14 transects (N1 to N7 and S1 to S7) along the longitudinal gradient, and (b) 9 transects (a to $i$ ) along the beach width gradient at Grimsby. In (a), transects are arranged along the $x$-axis in order, from upper to lower estuary

model for total biomass (Table 2), the sum of the biomasses of the first 3 models was used to derive total biomass for subsequent model simulation. The analysis also indicated that salinity, median particle size, silt content, transect slope, station slope and median depth of the beach are the 6 key environmental variables that can significantly explain the variation in macrobenthic biomass along the longitudinal as well as the beach width gradient. The equations for the 3 mean biomasses can be expressed as:

$$
\begin{gathered}
\text { mBiomass }= \\
\left(\mathrm{e}^{0.044 \times \mathrm{SIL}+7.38 \times \mathrm{T}-\mathrm{SLO}-2.19 \times \mathrm{S}-\mathrm{SLO}-7.41}-1\right) / 1000 \\
\mathrm{CBiomaSS}= \\
\left(\mathrm{e}^{3.78 \times \mathrm{SAL}+13.34 \times \mathrm{MD}-0.41 \times \mathrm{SIL}+3.38 \times \mathrm{S}-\mathrm{SLO}-45.57}-1\right) / 1000 \\
\mathrm{oBiomaSS}= \\
\left(\mathrm{e}^{1.58 \times \mathrm{SAL}+0.036 \times \mathrm{SIL}-0.016 \times \mathrm{M}-\mathrm{DEP}+1.20}-1\right) / 1000
\end{gathered}
$$

where mBiomass, cBiomass and oBiomass represent the mean biomass ( $\mathrm{g}$ AFDW $\mathrm{m}^{-2}$ ) for $M$. balthica, $C$. edule and other macrobenthos at the transect scale, respectively, and SAL, MD, SIL, T-SLO, S-SLO and MDEP denote values for salinity (log-transformed), median particle size (phi), silt content (\%), transect slope, station slope and median depth of the beach (\%). The model for predicting mean total biomass can therefore be expressed as:

$$
\begin{gathered}
\text { Total biomass }\left(\mathrm{g} \text { AFDW m} \mathrm{m}^{-2}\right)= \\
\text { mBiomass + cBiomass + oBiomass }
\end{gathered}
$$

Based on Eqs. (6) to (9), Fig. 3 shows the predicted against observed biomasses along the longitudinal gradient on the Humber estuary and local beach width gradient at Grimsby, respectively. The system average biomass based on the field observation was $8.65 \mathrm{~g}$ AFDW m ${ }^{-2}$ (Table 1), which gives a system total macrobenthic biomass of $1037.5 \mathrm{t}$ AFDW. The model predictions for the 2 values were $8.29 \mathrm{~g} \mathrm{AFDW} \mathrm{m}^{-2}$ and 
Table 2. Results of multiple regression analysis of the 4 macrobenthic biomass categories against physical variables along both the longitudinal and beach width gradients $(n=23$ transects). n.c.: not calculated. See Table 1 for variable abbreviations

\begin{tabular}{|c|c|c|c|c|c|c|c|c|c|c|c|c|}
\hline \multirow[t]{2}{*}{ Model } & \multirow[b]{2}{*}{ SS } & \multirow{2}{*}{$\overline{\mathrm{df}}$} & \multicolumn{3}{|c|}{ Dverall model summary } & \multirow[b]{2}{*}{$\mathrm{R}^{2}$} & \multirow[b]{2}{*}{ SE } & \multirow[t]{2}{*}{ Variable } & \multirow{2}{*}{$\begin{array}{l}\text { Model } \\
\text { coeffi- } \\
\text { cients }\end{array}$} & \multirow{2}{*}{$\begin{array}{c}\text { Partial } \\
\text { correlation } \\
\text { coefficients }\end{array}$} & \multirow[t]{2}{*}{$t$} & \multirow[t]{2}{*}{$\mathrm{p}$} \\
\hline & & & MS & $F$ & $\mathrm{p}$ & & & & & & & \\
\hline \multicolumn{13}{|c|}{ Macoma balthica } \\
\hline Regression & 132.3 & 3 & \multirow{4}{*}{$\begin{array}{c}44.1 \\
1.46\end{array}$} & 30.2 & \multirow[t]{4}{*}{$<0.0001$} & \multirow[t]{4}{*}{0.80} & \multirow[t]{4}{*}{1.21} & (constant) & -7.414 & n.c. & -5.24 & $<0.0001$ \\
\hline Residual & 27.7 & 19 & & & & & & T-SLO & 7.382 & 0.86 & 7.28 & $<0.0001$ \\
\hline \multirow[t]{2}{*}{ Total } & \multirow[t]{2}{*}{160.0} & \multirow[t]{2}{*}{22} & & & & & & SIL & 0.044 & 0.77 & 5.22 & $<0.0001$ \\
\hline & & & & & & & & S-SLO & -2.189 & -0.51 & -2.57 & $<0.05$ \\
\hline \multicolumn{13}{|c|}{ Cerastoderma edule } \\
\hline Regression & 322.6 & 4 & \multirow{5}{*}{$\begin{array}{c}80.7 \\
2.55\end{array}$} & 31.6 & \multirow[t]{5}{*}{$<0.0001$} & \multirow[t]{5}{*}{0.85} & \multirow[t]{5}{*}{1.60} & (constant) & -45.567 & n.c. & -5.00 & $<0.0001$ \\
\hline Residual & 45.9 & 18 & & & & & & SIL & -0.412 & -0.77 & -5.11 & $<0.0001$ \\
\hline \multirow[t]{3}{*}{ Total } & \multirow[t]{3}{*}{368.5} & \multirow[t]{3}{*}{22} & & & & & & MD & 13.337 & 0.73 & 4.53 & $<0.001$ \\
\hline & & & & & & & & SAL & 3.777 & 0.66 & 3.78 & $<0.01$ \\
\hline & & & & & & & & S-SLO & 3.383 & 0.70 & 4.19 & $<0.001$ \\
\hline \multicolumn{13}{|l|}{ Others } \\
\hline Regression & 47.6 & 3 & \multirow{4}{*}{$\begin{array}{c}15.9 \\
0.49\end{array}$} & 32.3 & \multirow[t]{4}{*}{$<0.0001$} & \multirow[t]{4}{*}{0.81} & 0.70 & (constant) & 1.201 & n.c. & 1.28 & $<0.5$ \\
\hline Residual & 9.3 & 19 & & & & & & SIL & 0.036 & 0.87 & 7.78 & $<0.0001$ \\
\hline Total & 57.0 & 22 & & & & & & SAL & 1.584 & 0.83 & 6.48 & $<0.0001$ \\
\hline & & & & & & & & M-DEP & -0.016 & -0.52 & -2.65 & $<0.05$ \\
\hline Total & & & & & & & & & & & & \\
\hline Regression & 63.2 & 3 & 21.1 & 15.5 & $<0.0001$ & 0.66 & 1.17 & (constant) & -4.447 & n.c. & -2.22 & $<0.05$ \\
\hline Residual & 25.8 & 19 & 1.36 & & & & & S-SLO & 1.515 & 0.52 & 2.69 & $<0.05$ \\
\hline Total & 89.1 & 22 & & & & & & SAL & 1.887 & 0.65 & 3.74 & $<0.01$ \\
\hline & & & & & & & & $\mathrm{MD}$ & 0.872 & 0.58 & 3.10 & $<0.01$ \\
\hline
\end{tabular}

995.4 $\mathrm{t}$ AFDW, respectively, which fall within $\pm 5 \%$ of the observed values. These results and the graphical fit shown in Fig. 3 suggest that the models provide a reasonable description of how macrobenthic biomass in the Humber estuary can be predicted from the 6 key environmental variables.

By coupling Eqs. (6) to (9), we were able to predict changes in estuarine topography, sediment, and salinity distributions, and hence macrobenthic biomass, for a range of sea-level rise scenarios. Fig. 1a shows the location of 14 transects (N1 to N7 and S1 to S7) for the model simulations and the area represented by each transect. The model outputs shown in Fig. 3a were used as a baseline against which the effects of environmental change can be compared. System total intertidal area $\left(\mathrm{km}^{2}\right)$, system average biomass (g AFDW $\mathrm{m}^{-2}$ ), and system total biomass (t) can be expressed as:

$$
\begin{gathered}
\text { System total intertidal area }=\Sigma A R\left(T_{n}\right) \\
\text { System average biomass }= \\
\Sigma\left[\text { tBiomass }\left(T_{n}\right) \times A R\left(T_{n}\right)\right] / \Sigma A R\left(T_{n}\right) \\
\text { System total biomass }= \\
\Sigma\left[\text { tBiomass }\left(T_{n}\right) \times A R\left(T_{n}\right)\right]
\end{gathered}
$$

where $A R\left(T_{n}\right)$ and tBiomass $\left(T_{n}\right)$ denote the area $\left(\mathrm{km}^{2}\right)$ and mean total biomass (g AFDW m ${ }^{-2}$ ) (Eq. 9) at transect $n(1$ to 14$)$, respectively. $\mathrm{AR}\left(\mathrm{T}_{\mathrm{n}}\right)$ and tBiomass $\left(\mathrm{T}_{\mathrm{n}}\right)$ change as sea level rises and environmental parameters change (Eqs. 6 to 9), and Eqs. (10) to (12) were used to calculate percentage loss or gain against the baseline. The rate of sea-level rise relative to land has been 2 to $2.5 \mathrm{~mm} \mathrm{yr}^{-1}$ over the last $100 \mathrm{yr}$ in the Humber estuary (Edwards \& Winn 2006), and is expected to increase up to $6 \mathrm{~mm} \mathrm{yr}^{-1}$ over the next $50 \mathrm{yr}$ (MAFF 1999), indicating that sea level could rise by 0.1 to $0.3 \mathrm{~m}$ over that period. Thus, the effects of sea-level increases of $0.1,0.3$ and $0.5 \mathrm{~m}$ were explored in our simulations.

\section{Saline intrusion}

When sea level rises, water depth increases. This is likely to cause intrusion of saline water up the estuary (Jones 1994). The relationship between salinity intrusion and sea-level rise was derived for the Humber estuary as follows: the estuary has a depth of $<5 \mathrm{~m}$ around Trent Falls, increasing to almost $20 \mathrm{~m}$ at Spurn Head relative to ordnance datum (Jickells et al. 2000). Given the distance between Trent Falls and Spurn Head of $\sim 60 \mathrm{~km}$, the water body of the Humber estuary can be expressed as a triangle (Fig. 4). If sea level rises by $h \mathrm{~m}$, then the horizontal distance $A$ to $A^{\prime}$ is the salinity intrusion upstream. Because triangle $A B C$ is analogous to triangle $A^{\prime} B C^{\prime}$ when sea level rises by $h \mathrm{~m}$, the horizontal distance between $A^{\prime}$ and $A$ is $4 h \mathrm{~km}$. Using this approach, salinity distributions were estimated to migrate up river by $0.4,1.2$ and $2.0 \mathrm{~km}$ in response to 

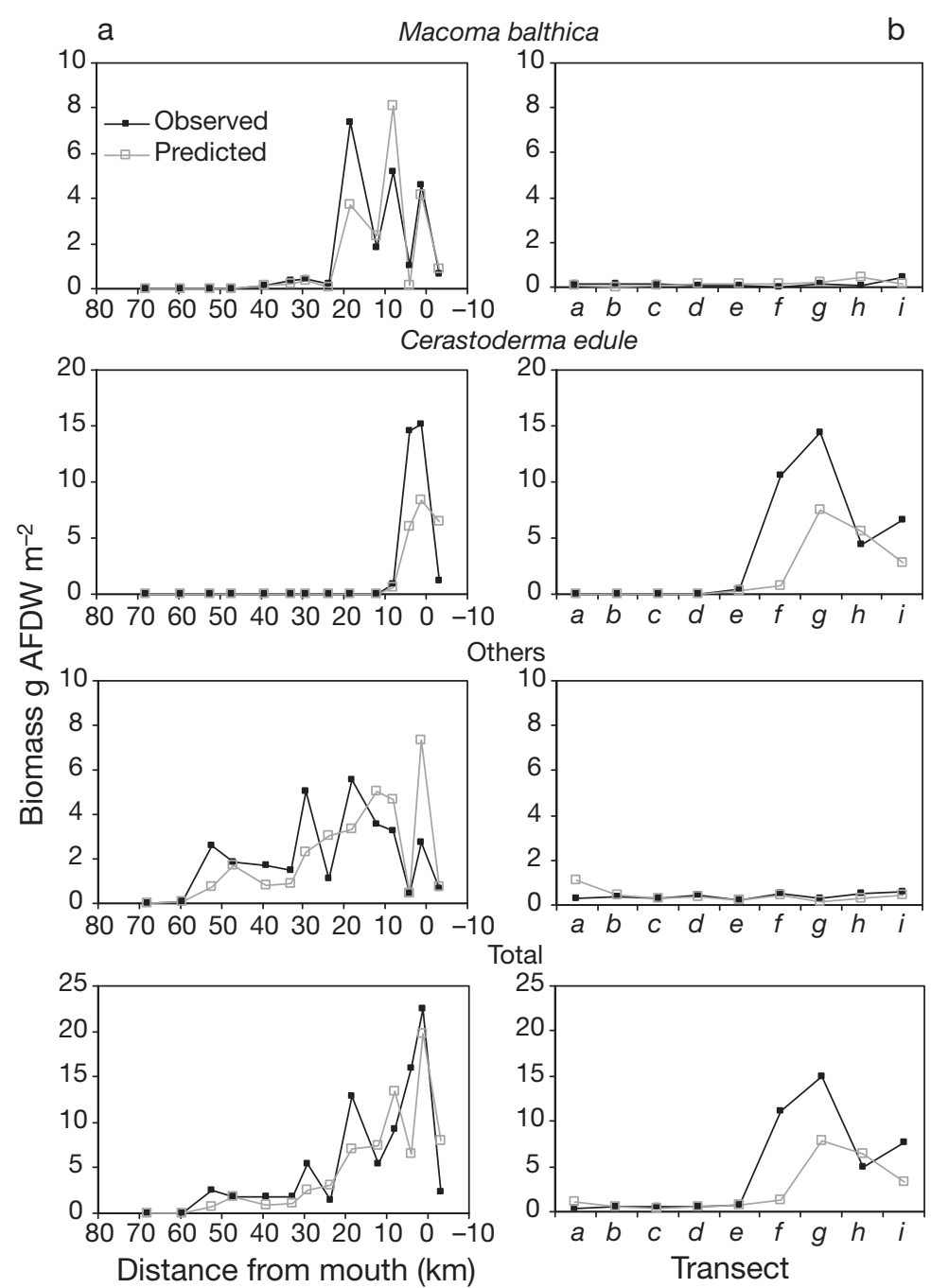

b

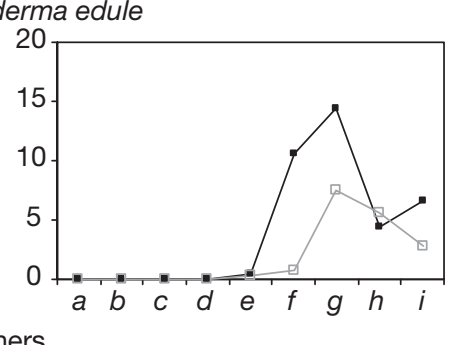

Others

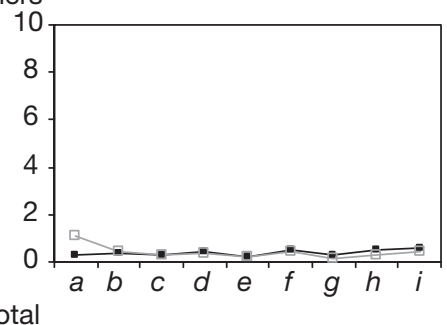

Total

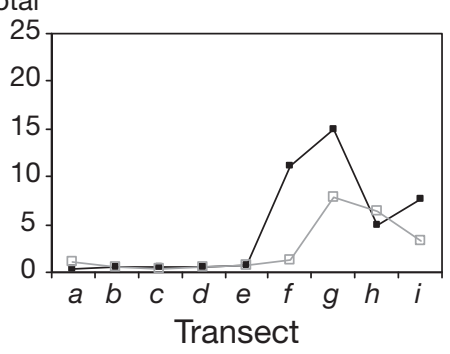

Fig. 3. Observed and model-predicted biomass ( $\mathrm{g}$ AFDW $\mathrm{m}^{-2}$ ) for Macoma balthica, Cerastoderma edule, other macrobenthos, and total macrobenthos along the (a) system longitudinal gradient and (b) local beach width gradient at Grimsby. The model-predicted total biomass was derived from the sum of the biomass of $M$. balthica, $C$. edule and other macrofauna. In (a), negative values along the $x$-axis indicate areas outside the mouth

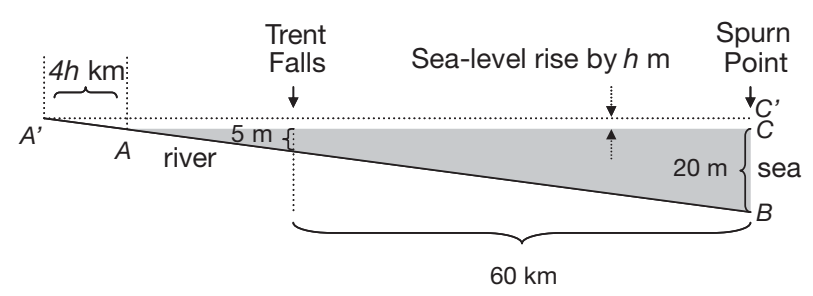

Fig. 4 . Humber estuary showing the depth of Trent Falls and
Spurn Point. Shaded triangle $A B C$ represents the current wa-
ter body in the Humber estuary, and dotted line $A^{\prime} C^{\prime}$ repre-
sents the sea level which has risen by $h$ m. Horizontal distance
$A^{\prime} A$ indicates the distance where salinity has intruded
upriver, which can be calculated as $4 h \mathrm{~km}$

Fig. 4. Humber estuary showing the depth of Trent Falls and
Spurn Point. Shaded triangle $A B C$ represents the current wa-
ter body in the Humber estuary, and dotted line $A^{\prime} C^{\prime}$ repre-
sents the sea level which has risen by $h$ m. Horizontal distance
$A^{\prime} A$ indicates the distance where salinity has intruded
upriver, which can be calculated as $4 \mathrm{~h} \mathrm{~km}$

Fig. 4. Humber estuary showing the depth of Trent Falls and
Spurn Point. Shaded triangle $A B C$ represents the current wa-
ter body in the Humber estuary, and dotted line $A^{\prime} C^{\prime}$ repre-
sents the sea level which has risen by $h$ m. Horizontal distance
$A^{\prime} A$ indicates the distance where salinity has intruded
upriver, which can be calculated as $4 \mathrm{~h} \mathrm{~km}$

Fig. 4. Humber estuary showing the depth of Trent Falls and
Spurn Point. Shaded triangle $A B C$ represents the current wa-
ter body in the Humber estuary, and dotted line $A^{\prime} C^{\prime}$ repre-
sents the sea level which has risen by $h$ m. Horizontal distance
$A^{\prime} A$ indicates the distance where salinity has intruded
upriver, which can be calculated as $4 \mathrm{~h} \mathrm{~km}$

Fig. 4. Humber estuary showing the depth of Trent Falls and
Spurn Point. Shaded triangle $A B C$ represents the current wa-
ter body in the Humber estuary, and dotted line $A^{\prime} C^{\prime}$ repre-
sents the sea level which has risen by $h$ m. Horizontal distance
$A^{\prime} A$ indicates the distance where salinity has intruded
upriver, which can be calculated as $4 \mathrm{~h} \mathrm{~km}$

Fig. 4. Humber estuary showing the depth of Trent
Spurn Point. Shaded triangle $A B C$ represents the cu
ter body in the Humber estuary, and dotted line $A^{\prime}$
sents the sea level which has risen by $h$ m. Horizontal
$A^{\prime} A$ indicates the distance where salinity has
upriver, which can be calculated as $4 \mathrm{~h} \mathrm{~km}$ sea-level increases of $0.1,0.3$ and $0.5 \mathrm{~m}$, respectively. Using the 2003 survey data (Fig. 5), the relationship between salinity and distance from the mouth $(\mathrm{km})$ along the Humber estuary can be expressed as:

$$
\begin{gathered}
\operatorname{SAL}(x)= \\
0.0023 x^{2}-0.54 x+28.38
\end{gathered}
$$

where $\operatorname{SAL}(x)$ denotes the salinity at $x$ $\mathrm{km}$ from the mouth $\left(\mathrm{R}^{2}=0.99\right)$. If saline intrusion causes a shift in salinity distribution by $x_{1} \mathrm{~km}$ up the estuary, a new salinity value for a fixed transect position can be expressed as SAL $\left(x-x_{1}\right)$. New salinities were predicted for $x_{1}$ values of $0.4,1.2$ and $2.0 \mathrm{~km}$ (equivalent to a sea-level rise of $0.1,0.3$ and $0.5 \mathrm{~m}$, respectively).

\section{Sediment changes}

Increased water depth is likely to result in enhanced wave and tidal energy, which in turn will affect sediment processes in estuarine environments (Crooks 2004). Mudflats will migrate landwards and upstream as water depth increases due to sea-level rise, and will probably be replaced by beaches with coarser particles, which may similarly migrate from exposed downstream environments and more open coasts (Pethick 1996). In addition, saline intrusion will shift the turbidity maximum up river, intensifying the deposition of finer particles particularly 
around the middle and upper regions of the estuary. Thus, sea-level rise will likely lead to a migration of the entire sedimentary distribution up the estuary, leaving the lower and outer regions of the estuary sandier and the inner estuary muddier. In the present study, the extent of sediment migration is assumed to be similar to that of salinity (see above), shifting up river by 0.4 , 1.2 and $2.0 \mathrm{~km}$ in response to sea-level increases of 0.1 , 0.3 and $0.5 \mathrm{~m}$, respectively. Because the spatial patterns of sediment distribution were markedly different between the north and south banks of the Humber estuary around the lower region (Fig. 6), equations were formulated separately for both banks so that sediment properties could be more precisely expressed as a function of distance from the mouth.

Based on the 2003 survey (Fig. 7), the relation between silt content and distance from the mouth can be expressed by 2 separate equations (one a logistic curve up to $\sim 20 \mathrm{~km}$, and the other a 5th-order polynomial at $>20 \mathrm{~km}$ from the mouth) as follows:

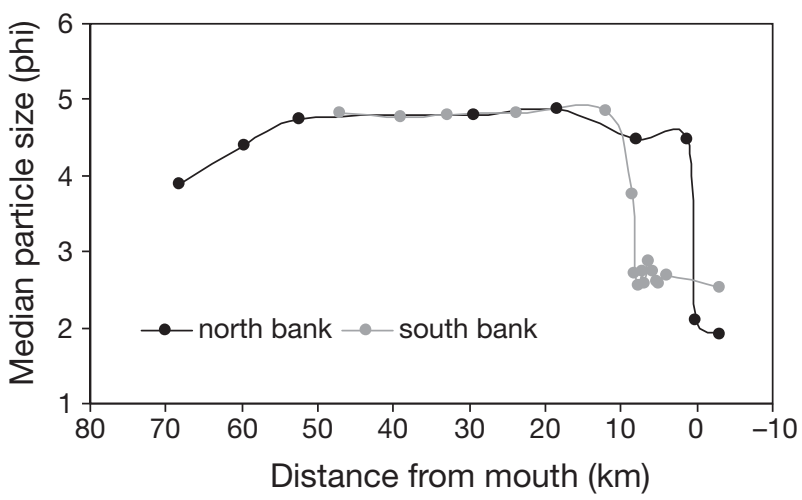

Fig. 6. Humber estuary. Relationship between average median particle size (phi) and distance from the mouth $(\mathrm{km})$ on the $(\bullet)$ north, and $(\bullet)$ south banks. 'phi' units increase with decreasing sediment particle size as defined in the text. Negative values along $x$-axis indicate locations outside the mouth

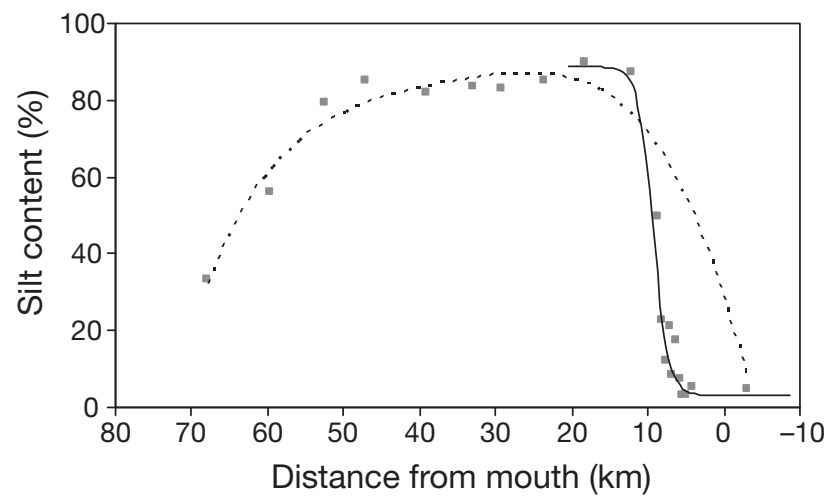

Fig. 7. Humber estuary. Relationship between mean silt content $(\%)$ and distance from the mouth $(\mathrm{km})$ on the south bank with 2 fitted curves (Eqs. 14 \& 15). Negative values along $x$-axis indicate locations outside the mouth

$$
\begin{gathered}
\operatorname{SIL}_{\text {south }}(x)=\left[83.0 /\left(1+\mathrm{e}^{8.5+x}\right)\right]+3.0 \\
\operatorname{SIL}_{\text {south }}(x)=6.6 \times 10^{-8} x^{5}-2.0 \times 10^{-5} x^{4}+ \\
3.9 \times 10^{-3} x^{3}-0.24 x^{2}+6.26 x+30.25
\end{gathered}
$$

where $\operatorname{SIL}_{\text {south }}(x)$ denotes the silt content at a location $x \mathrm{~km}$ from the mouth on the south bank of the estuary for $x<20 \mathrm{~km}$ (Eq. 14) and $x>20 \mathrm{~km}$ (Eq. 15). Similarly, the equation for silt content on the north bank was derived as follows:

$$
\operatorname{SIL}_{\text {north }}(x)=\left[84.7 /\left(1+\mathrm{e}^{-1.0+0.7 x}\right)\right]+1.3
$$

for $x<20 \mathrm{~km}$. Silt contents at sites $>20 \mathrm{~km}$ on the north bank were derived using Eq. (15) due to the similar trends observed between north and south banks in the 2003 survey.

Fig. 8 shows the relationship between median particle size and silt content in the Humber estuary. Because of the strong linear relation between these 2 variables $(y=$ $\left.0.030 x+2.3 ; R^{2}=0.95\right)$, median particle size can be expressed as a function of distance from the mouth by using Eqs. (14) to (16) and the linear equation shown in Fig 8:

$$
\begin{aligned}
& \operatorname{MD}_{\text {south }}(x)=0.030 \times \operatorname{SIL}_{\text {south }}(x)+2.3 \\
& \operatorname{MD}_{\text {north }}(x)=0.030 \times \operatorname{SIL}_{\text {north }}(x)+2.3
\end{aligned}
$$

where $\mathrm{MD}_{\text {south }}(x)$ and $\mathrm{MD}_{\text {north }}(x)$ represent the median particle size at a location $x \mathrm{~km}$ from the mouth of the Humber estuary. Thus, migrations of these 2 sediment properties (median particle size and silt content) can now be expressed as a function of distance by changing the value of $x$ in the above equations.

\section{Morphological variables}

Intertidal area loss $\left(\mathrm{km}^{2}\right)$ at transect $n$ can be expressed as:

$$
\text { Intertidal loss }\left(\mathrm{T}_{n}\right)=\left[\mathrm{SLR} / \mathrm{TR}\left(\mathrm{T}_{n}\right)\right] \times \mathrm{AR}\left(\mathrm{T}_{n}\right)
$$

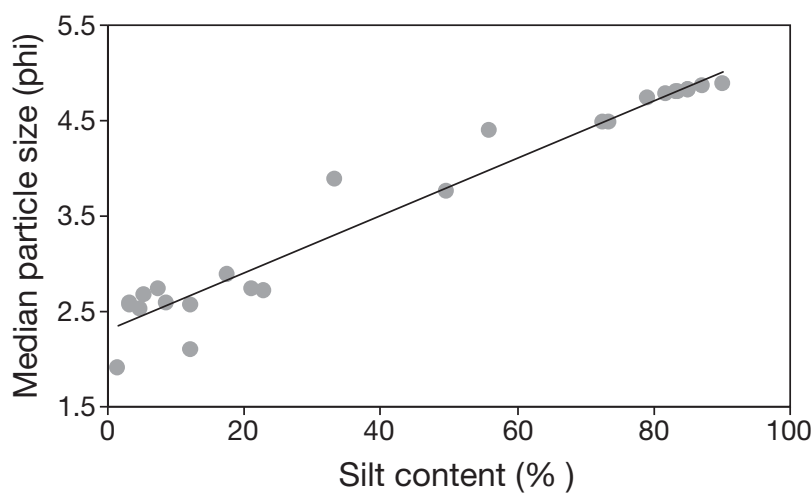

Fig. 8. Humber estuary and Grimsby. Relationship between average median particle size (phi) and mean silt content (\%) for each transect, with linear fitted line. 'phi' units increase with decreasing sediment particle size as defined in the text 
where SLR and TR $\left(\mathrm{T}_{n}\right)$ denote sea-level rise $(\mathrm{m})$ and local mean tidal range $(\mathrm{m})$ at transect $n$, respectively. The $\Sigma\left[\right.$ Intertidal $\left.\operatorname{loss}\left(\mathrm{T}_{n}\right)\right]$ was compared with the current intertidal area to calculate the percentage total loss of intertidal area in the Humber estuary.

From the field observations at Grimsby, both transect slope and station slope were found to become steeper when beaches became squeezed (Fig. 9a,b). Transect $e$ was located on the edge of the natural zone and beach widths were progressively squeezed towards transect a (Fig. 1b). If an area of land claim extends up to MLWL, no intertidal flat is left in front of the sea defence wall and tidal movement occurs vertically between MLWL and MHWL on the defence wall. The most squeezed end of the Grimsby intertidal flat (beyond transect a) reflects a scenario where sea-level rise of the local tidal range of $4.55 \mathrm{~m}$ has taken place, and transect e reflects the baseline scenario where no sea-level rise has occurred. Similarly, the beach width from transect $e(833 \mathrm{~m})$ through $a$ to the squeezed end $(0 \mathrm{~m})$ corresponds to the extent of sea-level rise from 0
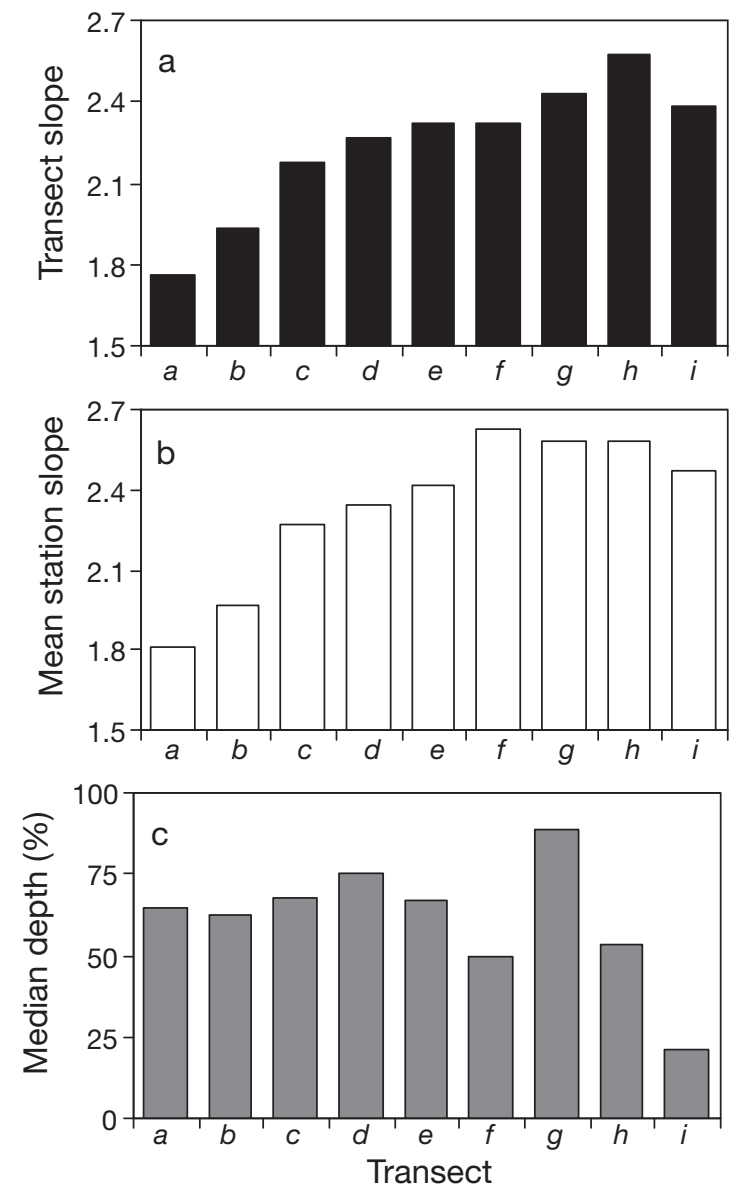

Fig. 9. Grimsby. (a) Transect slope, (b) mean station slope, and (c) median tidal depth of beach (\%), for 9 transects (a to i) along the beach width gradient. Higher slope values in (a) and (b) indicate shallower slopes as defined in the text to $4.55 \mathrm{~m}$. Using the field measurements made at Grimsby, transect slope values were plotted against beach width (Fig. 10) to derive the following relationship:

$$
\text { Transect slope }(\text { WID) }=0.42 \times \operatorname{Ln}(\text { WID })-0.52
$$

where WID and Ln(WID) denote beach width (m) and natural log-transformation of the beach width, respectively $\left(\mathrm{R}^{2}=0.95\right)$. Using Eq. (20), it is now possible to predict how transect slope will change in response to sea-level rise. Because transect slope is a function of beach width (Eq. 20), a change in transect slope (\%) due to a decrease in beach width as a result of sealevel rise can be expressed as:

$$
\begin{gathered}
\text { Change in transect slope }=100 \times\{1- \\
{[\text { transect slope }(\text { WID) } / \text { transect slope }(833)]\}}
\end{gathered}
$$

Because the squeeze in beach width mimics the extent of sea-level rise, the increase in sea level can be expressed as a function of beach width (WID) as follows:

Increase in sea level $=4.55 \times[1-($ WID / 833) $]$

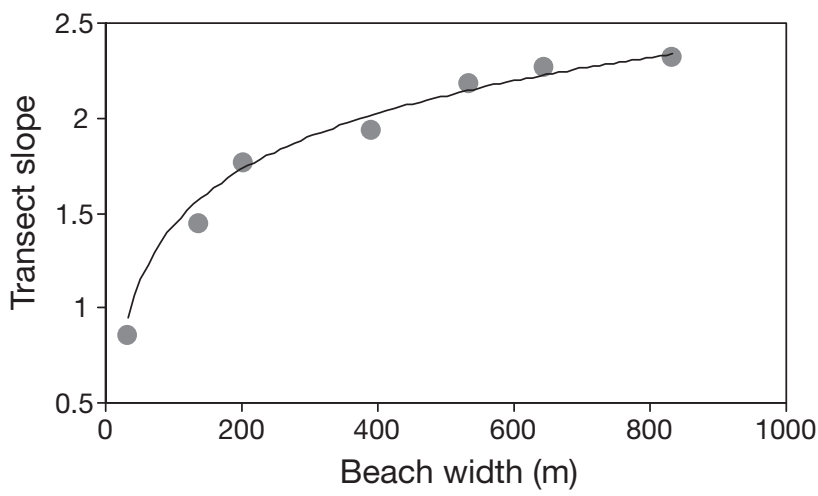

Fig. 10. Grimsby. Relationship between transect slope and beach width $(\mathrm{m})$ based on 7 observations, including 5 from transects $a$ to $e$ along the beach width gradient

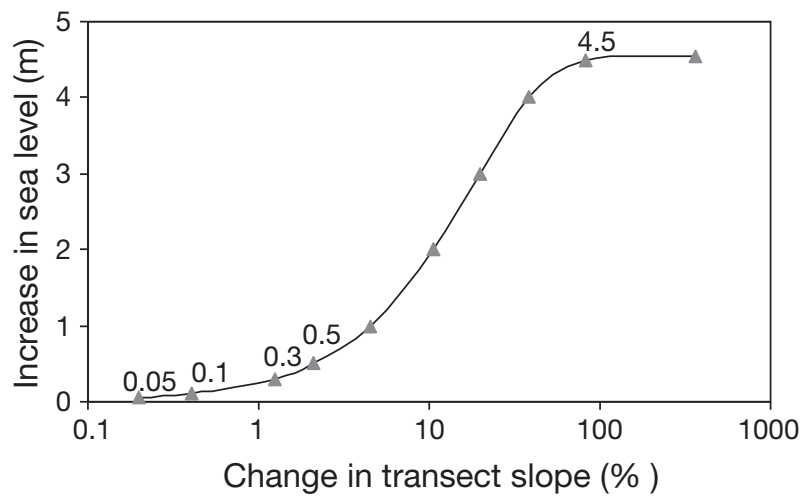

Fig. 11. Humber estuary. Relationship between increase in sea level $(\mathrm{m})$ and expected change in transect slope (\%) 


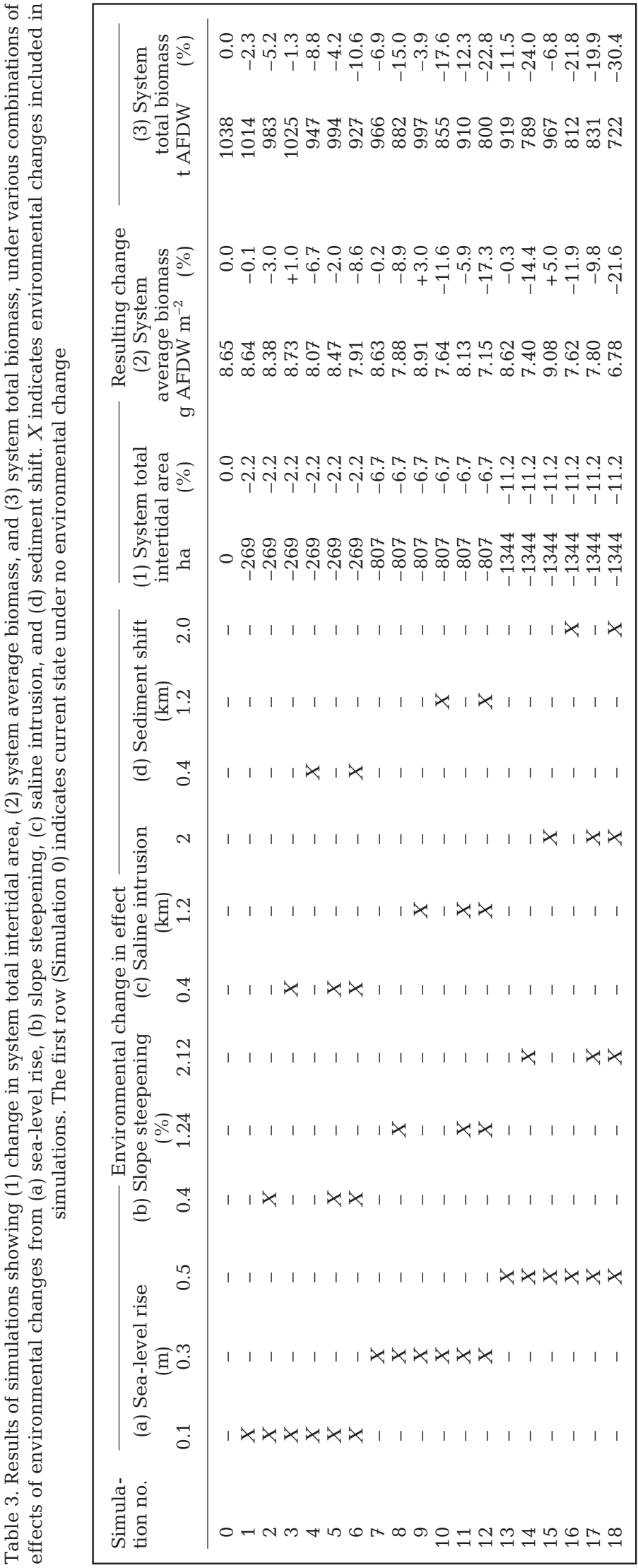

Both Eqs. (21) and (22) are a function of beach width (WID), and the relationship between increase in sea level (m) and change in transect slope (\%) can thus be mathematically deduced from Eqs. (20) to (22) as shown in Fig. 11, indicating that transect slope becomes steeper by $0.40,1.24$ and $2.12 \%$ when the sea level rises by $0.1,0.3$ and $0.5 \mathrm{~m}$, respectively. Station slope was also assumed to become steeper at the same rate as transect slope in response to sea-level rise, based on their similar patterns of change (Fig. 9a,b).

Finally, field observations at Grimsby showed that median depth of the beach does not change despite the extent of coastal squeeze observed between transect $a$ and e (Fig. 9c). Therefore, median depth was assumed to remain unchanged in response to sea-level rise for the model simulation.

\section{Simulation results}

Using the equations described above, model simulations of the effects of sea-level increases of 0.1 , 0.3 and $0.5 \mathrm{~m}$ on environmental variables were derived by changing the values of $x \mathrm{~km}$ for salinity and sedimentary variables (Eqs. 13 to 18) or by changing the degree of sea-level rise for morphological variables (Eqs. 19 to 22). Inserting these new values of environmental variables into Eqs. (6) to (9) generates changes in macrobenthic biomass at the transect scale, and Eqs. (10) to (12) predict changes in (1) total area of intertidal flat, (2) system average biomass, and (3) system total biomass. These simulations are shown in Table 3. Several features emerge from the analysis:

(1) Sea level increases of $0.1,0.3$ and $0.5 \mathrm{~m}$ reduced intertidal area by 269 ha $(2.2 \%), 807$ ha $(6.7 \%)$ and 1134 ha $(11.2 \%)$, respectively. These reductions in tidal flat area alone would lead to respective losses in total macrobenthic biomass of $2.3,6.9$ and $11.5 \%$.

(2) When the effects of slope steepening were added, losses in total biomass doubled and system average biomass was also reduced by $3.0,8.9$ and $14.4 \%$ in response to sea-level rise of $01,0.3$ and $0.5 \mathrm{~m}$, respectively. Beach steepening could markedly reduce the amount of total macrobenthic biomass.

(3) When the effect of saline intrusion was combined with the effects of sea-level rise, system average biomass increased by 1.0, 3.0 and $5.0 \%$ under the 3 sea-level rise scenarios. The previously observed negative impacts of sea-level rise on total amount of macrobenthic biomass were almost halved, despite the considerable loss of intertidal area. This suggests that saline intrusion can create 
favourable conditions for macrobenthic invertebrates and could increase the quality of the intertidal area, potentially counteracting losses resulting from sealevel rise.

(4) Sediment shifts had the strongest negative impacts on total macrobenthic biomass when their effects were combined with sea-level rise, reducing system total biomass between 8.8 and $21.8 \%$, and system average biomass by $6.7,11.6$ and $11.9 \%$ under the 3 sea-level rise scenarios.

(5) The strong effect of sediment shift was also apparent when all the environmental effects were combined. Thus, for a sea-level rise of $0.3 \mathrm{~m}$, these combined effects reduced total biomass by $22.8 \%$, but when the effect of sediment shift was removed, the negative impact was almost halved to $12.3 \%$.

(6) Trends in the beach slopes observed at Grimsby (Fig. 10) and the clear relationship between mean salinity and distance from the mouth (Fig. 5) suggest that slope steepening and saline intrusion are likely to occur in response to sea-level rise. Thus, if sea level increases by $0.3 \mathrm{~m}$, as expected over the next $50 \mathrm{yr}$, we predict that the total macrobenthic biomass of the Humber estuary will decrease by at least 3.9 to $12.3 \%$. However, the effects of sediment change could well double the negative impacts on macrobenthic biomass should sediment migration occur to the extent simulated here.

\section{DISCUSSION}

This study has revealed a number of implications of sea-level rise for estuarine macrobenthic ecology and, consequently, for higher trophic levels dependent on the macrobenthos. At the local scale along the beach width gradient, the intertidal area at Grimsby was made steeper by coastal squeeze due to land claim (here used to mimic sea-level rise), with macrobenthic biomass correspondingly reduced as beach width decreased. The models constructed here indicate that saline intrusion would be able to partly compensate for losses in macrobenthic biomass, but that other anticipated environmental changes, such as slope steepening and sediment shift, could have much larger, overriding negative impacts on the quality of intertidal habitats, depending on their extent. Thus, the impacts of sea-level rise on the intertidal macrobenthos of the Humber estuary will depend on precisely how the key environmental variables change and interact in response to sea-level rise.

With respect to morphological change, the extent of coastal squeeze was represented by variation in beach width at Grimsby, and was best represented as a logarithmic association with transect slope (Fig. 10). This is consistent with the idea that, when a beach is trapped between a fixed sea defence and a rising sea level, the beach will experience steepening (Goss-Custard et al. 1990). There is also evidence that the majority of the coastline of England and Wales has steepened over the last century (Taylor et al. 2004), and this has been attributed to the removal of sediment from the foreshore by rising sea levels and the interruption of the landward transgression of the high water line by coastal defence walls (Crooks 2004, Taylor et al. 2004). Our data indicate that mean station slope becomes steeper when the beach becomes narrower, reducing the area of flatter surfaces within a beach. The steepness of the intertidal profile was significantly related to changes in the biomass of the bivalves Macoma balthica and Cerastoderma edule (Table 2), which together accounted for $>77 \%$ of the total macrobenthic biomass in the Humber estuary intertidal flat. Coastal squeeze resulting from sea-level rise is likely to produce steeper and more homogenous beach face profiles, which would have a significant negative overall impact on total macrobenthic biomass.

In the present study, the extent of sediment shift was simply assumed to be similar to that of saline intrusion; thus, there is uncertainty in predicting how precisely sediment change can occur in response to sea-level rise. However, sediment migration, as simulated here, still remains likely because intertidal habitats from Cleethorpes down to Mablethorpe on the south bank of the Humber estuary, which now are characterised by coarse sandy beaches, used to harbour extensive mudflats and saltmarshes before the 13th century (IECS 1994). The saltmarshes and the fine-grained mud have been gradually eroded and confined to the upper shore, to be replaced by sandy beaches. This was possibly due to local geomorphological changes induced by extreme events such as storms, floods and subsequent exposure to North Sea coastal processes (IECS 1994). Such large-scale changes in sediment characteristics from muddy to sandy habitats would have significant implications for estuarine intertidal ecology. Generally, muddy sediments with smaller median particle sizes and higher organic matter content support higher macrobenthic densities and biomass (McIntyre 1970, Jones 1988, Meire et al. 1991, Dauer 1993, Elliott et al. 1998, Beukema 2002, Ysebaert \& Herman 2002), and are normally associated with tide-dominated, dissipative beaches. However, as beaches become increasingly wave-dominated, they tend to become sandy flats that are highly reflective and support poorer infauna (Brown and McLachlan 1990, Brazeiro 2001, Rodil \& Lastra 2004). The sediment change experienced between Cleethorpes and Mablethorpe may well extend to the inner regions of the Humber estuary in response to rising sea levels 
and expected increases in extreme events. Given the catastrophic consequences of such changes for estuarine ecology, as predicted by our model simulations, there is an urgent need to improve our understanding of such important physical processes.

Although field observations and model simulations have illustrated the negative impacts of slope steepening resulting from coastal squeeze, our results say little about the mechanisms responsible for the relationship between transect slope or median depth and macrobenthic biomass. Goss-Custard et al. (1990) have implied that narrower and steeper beaches become more concave through erosion, thus reducing exposure time at low tide. Such reduction of exposure time may affect the production of benthic microalgae, which play an important role in estuarine ecosystems (Heip et al. 1995, Herman et al. 1999). Further, macrobenthic larval settlement may be adversely affected on narrower and steeper beaches due to the reduction in low-energy areas essential for successful early bivalve recruitment (Bouma et al. 2001). Other biological factors may also be important. For example, the study area in Grimsby was dominated by Cerastoderma edule, known to be affected by predation from crustacean species such as Crangon crangon (brown shrimps) and Carcinus maenas (shore crabs) (Richards et al. 2002, Huxham \& Richards 2003). In the western Wadden Sea, analyses of long-term data sets show that high biomasses of C. crangon are associated with low abundances of spat of C. edule and Macoma balthica (Beukema 2005). Further, C. maenas is capable of removing all juvenile $C$. edule from some areas, and their distribution is sediment specific, with higher densities in muddy than in sandy substrata (Richards et al. 1999). Such epibenthic predators surge onto intertidal areas with the tide. If squeezed beaches increase the access of such predators by reducing the topographic heterogeneity of wider beaches, this could result in high levels of predation on $C$. edule on narrower, squeezed beaches.

The macrobenthic models developed here provide a basis for predicting changes in the biomass of intertidal macrobenthos in response to sea-level rise. We believe that our findings on the relative importance of salinity intrusion, beach slope, and sediment shifts are robust for the Humber estuary, and that they probably apply to similar types of North Sea estuaries. However, estuaries and tidal flat areas which are geographically and topologically different, such as those with narrow entrances, may respond quite differently to sea-level rise. Another consideration is that only one region was chosen for closer examination of coastal squeeze. The more intense sampling from Grimsby may have overemphasised this region in the models, which could mean that predictions for the lower estuary are better than those for the rest of the estuary. Statistical modelling requires large amounts of data over a wide range of habitats (Thrush et al. 2003), and in this respect, more data from other locations should be incorporated into the models to make quantitative predictions more reliable. For simplicity, our model did not incorporate the impacts of several important environmental factors such as inter-annual variability in climatic conditions, increase in ambient temperature, increased occurrence of extreme climatic events, change in freshwater input, and change in channel depth in the estuary. It would therefore be interesting to combine estimates of such environmental shifts with our modelling approach in future work.

Acknowledgements. We thank Natural England, Carter Jonas and Associated British Ports (ABP) for access to the study site, and the British Oceanographic Data Centre (BODC) for providing LOIS RACS (C) Marine I and RACS (A) data sets. The advice and helpful comments of M. Elliott, S. Kojima and M. Bulling are greatly appreciated. We also thank R. Toriumi, K. Kanzaki, S. Takahashi, T. Sawamura, Y. Hasegawa, N. Hasegawa, J. Minx, T. Wang, K. Mikami, K. Mori, K. Numao, K. Shin, and Y. Hirayama who volunteered significant help with the fieldwork.

\section{LITERATURE CITED}

Baker JM, Crothers JH (1987) Intertidal rock. In: Baker JM, Wolff WJ (eds) Biological surveys of estuaries and coasts. Cambridge University Press, Cambridge, p 157-197

Beukema JJ (2002) Expected change in the benthic fauna of Wadden sea tidal flats as a result of sea-level rise or bottom subsidence. J Sea Res 47:25-39

$>$ Beukema JJ, Dekker R (2005) Decline of recruitment success in cockles and other bivalves in the Wadden Sea: possible role of climate change, predation on postlarvae and fisheries. Mar Ecol Prog Ser 287:149-167

Boesch DF (1977) A new look at the zonation of the benthos along the estuarine gradient. In: Coull BC (ed) Ecology of marine benthos. Belle W. Baruch Library in Marine Science, University of South Carolina Press, Columbia, SC, p 245-266

> Bouma H, Duiker JMC, de Vries PP, Herman PMJ, Wolff WJ (2001) Spatial pattern of early recruitment of Macoma balthica (L.) and Cerastoderma edule (L.) in relation to sediment dynamics on a highly dynamic intertidal sandflat. J Sea Res 45:79-93

- Brazeiro A (2001) Relationship between species richness and morphodynamics in sandy beaches: What are the underlying factors? Mar Ecol Prog Ser 224:35-44

Brown AC, McLachlan A (1990) Ecology of sandy shores. Elsevier, Amsterdam

Crooks S (2004) The effect of sea-level rise on coastal geomorphology. Ibis 146:18-20

Dankers N, Kühl H, Wolff WJ (1981) Invertebrates of the Wadden Sea. A. A. Balkema, Rotterdam

> Dauer DM (1993) Biological criteria, environmental health and estuarine macrobenthic community structure. Mar Pollut Bull 26:249-257

Edwards AMC, Winn PSJ (2006) The Humber estuary, Eastern England: strategic planning of flood defences and habitats. Mar Pollut Bull 53:165-174 
Elliott M, Kingston PF (1987) The sublittoral benthic fauna of the estuary and Firth of Forth, Scotland. Proc R Soc Edinb B 93:449-465

Elliott M, Nedwell S, Jones NV, Read SJ, Cutts ND, Hemingway KL (1998) Intertidal sand and mudflats \& subtidal mobile sandbanks: an overview of dynamic and sensitivity characteristics for conservation management of marine SACs. Institute of Estuarine and Coastal Studies, University of Hull

Fujii T (2007) Spatial patterns of benthic macrofauna in relation to environmental variables in an intertidal habitat in the Humber estuary, UK: developing a tool for estuarine shoreline management. Estuar Coast Shelf Sci 75:101-119

Galbraith H, Jones R, Park R, Clough J, Herrod-Julius S, Harrington B, Page G (2002) Global climate change and sealevel rise: potential losses of intertidal habitat for shorebirds. Waterbirds 25:173-183

Goss-Custard JD, McGrorty S, Kirby R (1990) Inshore birds of the soft coasts and sea-level rise. In: Beukema JJ, Wolff WJ, Brouns JJWM (eds) Expected effects of climatic change on marine coastal ecosystems. Kluwer Academic Publishers, Dordrecht, p 189-193

Hartley JP, Dicks B, Wolff WJ (1987) Processing sediment macrofauna samples. In: Baker JM, Wolff WJ (eds) Biological surveys of estuaries and coasts. Cambridge University Press, Cambridge, p 131-139

Heip CHR, Goosen NK, Herman PMJ, Kromkamp J, Middelberg JJ, Soetaert K (1995) Production and consumption of biological particles in temperate tidal estuaries. Oceanogr Mar Biol Annu Rev 33:1-149

Herman PMJ, Middelburg JJ, Van De Koppel J, Heip CHR (1999) Ecology of estuarine macrobenthos. Adv Ecol Res 29:195-240

Holme NA, McIntyre AD (1971) Methods for the study of marine benthos. Blackwell Scientific Publications, Oxford and Edinburgh

- Huxham M, Richards M (2003) Can post larval bivalves select sediment type during settlement? A field test with Macoma balthica (L.) and Cerastoderma edule (L.). J Exp Mar Biol Ecol 288:279-293

IECS (1994) Humber estuary and coast. Institute of Estuarine and Coastal Studies, University of Hull

> Jickells T, Andrews J, Samways G, Sanders R and others (2000) Nutrient fluxes through the Humber estuarypast, present and future. Ambio 29:130-135

Jones NV (1988) Life in the Humber, invertebrate animals. In: Jones NV (ed) A dynamic estuary: man, nature and the Humber. Hull University Press, p 58-70

Jones G (1994) Global warming, sea-level change and the impact on estuaries. Mar Pollut Bull 28:7-14

Kennish MJ (2002) Environmental threats and environmental future of estuaries. Environ Conserv 29:78-107

Key RS (1983) Ecology of the infauna of Spurn Bight mudflats: an area proposed for reclamation. PhD thesis, University of Hull

Lawrence AJ, Soame JM (2004) The effects of climate change on the reproduction of coastal invertebrates. Ibis 146:29-39

Editorial responsibility: Richard Osman,

Edgewater, Maryland, USA
MAFF (1999) Flood defence and coastal defence appraisal guidance: economic appraisal. Ministry of Agriculture, Fisheries and Food, MAFF Publication PB 4650, London

McIntyre AD (1970) The range of biomass in intertidal sand, with special reference to the bivalve Tellina tenuis. J Mar Biol Assoc UK 50:561-575

McLusky DS, Elliott M (2004) The estuarine ecosystem. Ecology, threats and management. Oxford University Press

Meire PM, Seys JJ, Ysebaert TJ, Coosen J (1991) A comparison of the macrobenthic distribution and community structure between two estuaries in SW Netherlands. In: Elliott M, Ducrotoy JP (eds) Estuaries and coasts: spatial and temporal intercomparisons. Olsen \& Olsen, Fredensborg, p 221-230

Murby PJ (2001) The causes, extent and implications of intertidal change - a regional view from eastern England. MSc thesis, University of Hull

Pethick JS (1996) The geomorphology of mudflats. In: Nordstorm KF, Roman CT (eds) Estuarine shores: evolution, environment and human health. Cambridge University Press, Cambridge, p 41-62

Raffaelli D, Hawkins S (1996) Intertidal ecology. Kluwer Academic Publishers, Dordrecht

Richards MG, Huxham M, Bryant A (1999) Predation: a causal mechanism for variability in intertidal bivalve populations. J Exp Mar Biol Ecol 241:159-177

> Richards M, Edwards F, Huxham M (2002) The effects of the adult density of Macoma balthica on the recruitment of juvenile bivalves: a field experiment. J Sea Res 47:41-54

Rodil IF, Lastra M (2004) Environmental factors affecting benthic macrofauna along a gradient of intermediate sandy beaches in northern Spain. Estuar Coast Shelf Sci 61:37-44

Sutherland WJ (1996) Ecological census techniques: a hand book. Cambridge University Press, Cambridge

Taylor JA, Murdock AP, Pontee NI (2004) A macroscale analysis of coastal steepening around the coast of England and Wales. Geogr J 170:179-188

Thrush SF, Hewitt JE, Norkko A, Nicholls PE, Funnell GA, Ellis JI (2003) Habitat change in estuaries: predicting broad-scale responses of intertidal macrofauna to sediment mud content. Mar Ecol Prog Ser 263:101-112

Uncles RJ, Easton AE, Griffiths ML, Harris C and others (1998) Concentrations of suspended chlorophyll in the tidal Yorkshire Ouse and Humber estuary. Sci Total Environ 210-211:367-375

Winn PJS, Young RM, Edwards AMC (2003) Planning for the rising tides: the Humber Estuary shoreline management plan. Sci Total Environ 314-316:13-30

Ysebaert T, Herman PMJ (2002) Spatial and temporal variation in benthic macrofauna and relationship with environmental variables in an estuarine, intertidal soft-sediment environment. Mar Ecol Prog Ser 244:105-124

Ysebaert T, Herman PMJ, Meire P, Craeymeersch J, Verbeek H, Heip CHR (2003) Large-scale spatial pattern in estuaries: estuarine macrobenthic communities in the Schelde estuary, NW Europe. Estuar Coast Shelf Sci 57: 335-355

Submitted: March 19, 2008; Accepted: July 13, 2008

Proofs received from author(s): October 28, 2008 